\title{
DYNAMICS OF EMERGENT MACROPHYTES FOR 50 YEARS IN THE COASTAL LAKE ENGURE, LATVIA
}

\author{
Jānis Brižs \\ University of Latvia, Faculty of Geography and Earth Sciences, Alberta iela 10, Rīga, LV-1010, LATVIA
}

Communicated by Viesturs Melecis

\begin{abstract}
Coastal Lake Engure is a Ramsar site - a wetland of great importance due to its biological diversity and unique properties, especially its coverage of macrophytes, shallowness and size. This study assesses the dynamics of emergent macrophytes in the lake based on analysis of historical aerial photographs and digital orthophoto maps. The area of emergent macrophytes was shown to have increased by 781 ha (15 ha/year) in the period 1956 to 2007. The expansion rate differed during this period. Expansion was much faster (31 ha/year) from 1956 to 1972, but declined to 6 halyear from 1972 to 1994 and increased again to 11 ha/year from 1994 to 2007. The greatest rates of expansion of emergent macrophytes from 1956 to 1972 can be partly explained by ceased grazing and hay harvesting activities. As the area covered by emergent macrophytes changes seasonally, only remote sensing materials acquired during the same season should be compared. The open water territory in 2007 was only $22.9 \mathrm{~km}^{2}$, compared to $30.7 \mathrm{~km}^{2}$ in 1956. Emergent vegetation has been mostly limited to areas where the depth does not exceed $0.5 \mathrm{~m}$. Expansion of emergent vegetation was found to differ in various parts of the lake. The main factors affecting the rates of its development were wave disturbances, hydrological regime and ceased agricultural activities in the lake.
\end{abstract}

Key words: emergent vegetation, historical aerial photography, remote sensing, visual interpretation, wetland.

\section{INTRODUCTION}

The origin of lakes of the Baltic region is closely linked with geological processes at the end of the last glacial period (Zelčs and Markots, 2004). During the postglacial period, lake ecosystems were subjected to increasing inputs of matter and nutrients from the drainage basin. Inputs of nutrients promote development of aquatic vegetation and overgrowing of the lakes, making them more and more shallow. The natural process of overgrowing may last hundreds of years (Wetzel, 2001). However, man's economical activities can strongly increase its intensity (Lampert and Sommer, 2007), which can causes serious problems in the maintenance of biodiversity of lake ecosystems (Vīksne, 2000). It has also been reported that overgrowing can cause considerable methane emissions from reed belts and lower carbon accumulation (Nõges et al., 2008). Thus, lakes with large reed belts are net contributors to the greenhouse effect. It is of great importance to establish special management practices for sustainable development of lake ecosystems and preventing the loss of their biodiversity. The first step in this direction should be elaboration of methods for remote sensing of lakes for the assessment of long-term dynamics of emergent vegetation. Such studies are dependent on available data from the past periods (Dahdouh-Guebas and Koedam, 2008). Different approaches have been used until now. Lehmann (Lehmann and Lachavanne, 1998) argues that most of the information derived on past aquatic vegetation is from visually interpreted aerial photography. Historical aerial photography has been the only available data source for mapping dynamics of aquatic vegetation prior to 1973, when Landsat 1 was launched (Dekker et al., 2005). There are several examples of studies that have evaluated the dynamics of aquatic vegetation during the last half century (Fredriksen, 2004; Schmitz et al., 2009). However, none of these assessed expansion of emergent macrophytes. Lake Võrtsjärv was investigated within a time frame of 22 years using non parametrical Landsat TM satellite image analysis (Liira et al., 2010). Changes of aquatic vegetation were studied in Lake Luupuvesi by comparing black and white aerial photography of 1953 with infrared images of 1996 and 2007 (Valta-Hulkonen et al., 2004). Other efforts exist on assessment of emergent macrophyte change e.g. (Andersson, 2001; Partanen and Hellsetn, 2005).

Coastal Lake Engure is located on the western coast of the Gulf of Riga and is believed to have been formed about 4000 years ago (Vīksne, 1997). Its area is approximately 45 $\mathrm{km}^{2}$ and the average depth is less than $1 \mathrm{~m}$. Lake Engure, which is a Ramsar site, hosts high biodiversity. A total of 186 bird species (Vìksne, 2000) and 844 vascular plant species have been recorded in the Lake Engure Nature Park, in- 
cluding 81 endangered species (Gavrilova and Baroniņa, 2000). However, the expansion of emergent macrophytes has decreased suitable nesting sites and threatens the biological diversity of the lake (Vìksne, 2000). Eutrophication of the lake is reflected in an increase of macrophyte biomass (Sprinǵe et al., 2000). Therefore, understanding the development and dynamics of emergent macrophytes is crucial to understand other processes in the lake.

Until now, analysis and mapping of the lake Engure vegetation was performed using Landsat TM satellite images (Auniņš et al., 2000). However, this study was not intended to obtain data on the long-term dynamics of emergent vegetation. The aim of the present study is an assessment of the dynamics of emergent macrophytes during the last half century by aggregating the information included in historical aerial photographs and orthophoto maps taken during different periods of the last half century. The study tasks were: georeferencing of historical aerial photography and visual interpretation of remote sensing data; to detect changes in the area covered by emergent macrophytes in Lake Engure; to identify major factors controlling emergent macrophytes in Lake Engure; to determine how the dynamics of emergent macrophytes differ between aquatoriums.

\section{MATERIALS AND METHODS}

Study site. Lake Engure is located about $1.5 \mathrm{~km}$ from the coast of the Gulf of Riga in the Coastal Lowland. The water level of Lake Engure was lowered by $1.2 \mathrm{~m}$ to $1.7 \mathrm{~m}$ in 1842 (Eberhards and Saltupe, 2000), which decreased the area of the lake from about 90 to $45 \mathrm{~km}^{2}$. However, the size of Lake Engure reported in literature varies, as this is a question of interpretation of the aquatic and terrestrial vegetation transition zone, the area is estimated to be between 35 to $45 \mathrm{~km}^{2}$. Average depth of Lake Engure is reported to be 0.4 to $1 \mathrm{~m}$ and maximal depth up to $2.5 \mathrm{~m}$ (Vīksne, 1997). These figures vary as they depend on the base water level used in the study. It is important to note that the gyttja layer is 4 to $8 \mathrm{~m}$ deep, despite the shallowness of the lake (Eberhards and Saltupe, 2000).

The area of emergent macrophytes is estimated to have increased over the last 50 years (Vìksne, 1997). The only existing calculations indicate that the open water area is about $17 \mathrm{~km}^{2}$, of which about $5 \mathrm{~km}^{2}$ is covered by submerged macrophytes. The remaining area of the lake is covered by different communities of emergent macrophytes. The most dominant communities are Phragmitetum $\left(\sim 19 \mathrm{~km}^{2}\right)$ and Caricetum elatae variants $\left(\sim 12 \mathrm{~km}^{2}\right)$. The first mentioned is a species-poor association and consists mostly of Phragmites australis, while second is dominated by Carex elatae and Phragmites australis and may include Equisetum fluviatile and Menyanthes trifoliata. The second is present mostly in the Grebis peninsula and in the southern part of lake (Auniņš et al., 2000).

Materials. Historical aerial photographs and orthophoto maps were used to determine area of emergent macrophyte and the water border in 1956, 1972, 1981, 1994, 2004 and 2007. Although metadata about the photographs were not available, it was still possible to derive important information from the photographs themselves. Digital orthophoto images and their metadata were available from the Latvian Geospatial Information Agency. The scale of aerial photographs was estimated. See information about images in Table 1.

Most of the data were acquired in early summer (Table 1), but data for 2004 was acquired in autumn causing some risk of significant systematic error. For this reason the data from 2004 was excluded from the long-term analysis of emergent macrophyte dynamics. However, the 2004 data was used to estimate seasonal effects on emergent macrophytes in Lake Engure.

Historical aerial photography does not cover the entire lake area. Data from the next acquisition was used to fill this information gap. However, a significant area of the lake was not covered by images only in 1972 (see Fig. 1 and Table 1).

Isobaths with a $0.5 \mathrm{~m}$ interval were derived from topographical maps published in 1985 and 1986. The scale of the maps was $1: 10000$.

Methods. Each remote sensing image is as snapshot for a situation in the past. Remote sensing material acquisition dates marks borders of time periods used in the study. As differences of acquisition date are small (few days), they are disregarded in the study. Each time period investigated is designated by the years when images were acquired. For example, part of year 1972 belongs to time period 1956 to

Table 1

MAIN INFORMATION OF IMAGES EMPLOYED IN THE STUDY

\begin{tabular}{|c|c|c|c|c|c|c|c|}
\hline Year & Acquisition date & $\begin{array}{c}\text { Scale or resolution, } \\
\mathrm{m}\end{array}$ & $\begin{array}{c}\text { Area of image, } \\
\mathrm{km}^{2}\end{array}$ & No. of images & Colour mode & $\begin{array}{l}\text { Water level above } \\
\text { relative level, cm* }\end{array}$ & Coverage, $\%$ \\
\hline 1956 & $24.06 \& 25.06$ & $1: 12500$ & 5 & 31 & $\mathrm{~B} / \mathrm{W}$ & - & $99.7 \%$ \\
\hline 1972 & $29.06 \& 30.06$ & $1: 10000$ & 3.4 & 31 & RGB & 19 & $70.6 \%$ \\
\hline 1981 & 09.07 & $1: 10000$ & 9.5 & 18 & $\mathrm{~B} / \mathrm{W}$ & 45 & $98.3 \%$ \\
\hline 1994 & $26.06 \& 28.06$ & 1 & - & & $\mathrm{B} / \mathrm{W}$ & 53 & $100 \%$ \\
\hline 2004 & 13.10 & 1 & - & & RGB & 42 & $100 \%$ \\
\hline 2007 & 04.06 & 0.5 & - & & RGB, NIR & 41 & $100 \%$ \\
\hline
\end{tabular}

*Data of Ornithology Laboratory of the Institute of Biology, University of Latvia 


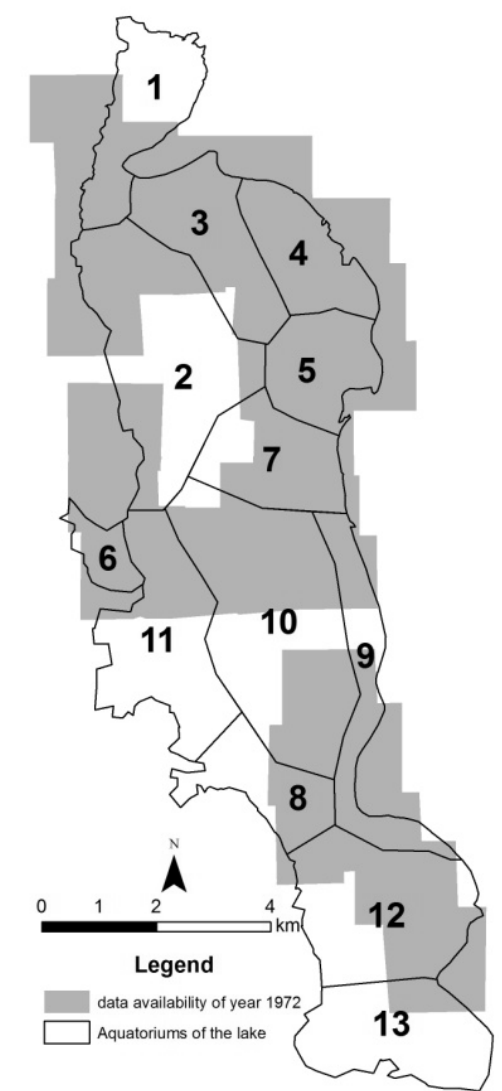

Fig. 1. Historical aerial photography coverage in 1972 and aquatoriums of Lake Engure.

1972 and to 1972 to 1981 . The exact acquisition dates are given in Table 1.

Historical aerial photography was acquired from the archive of the Institute of Biology, University of Latvia. All photographs were scanned at 600 dpi resolution. Black and white images were saved in JPEG file format as no pixel by pixel analysis was planned.

ESRI ArcGIS 9.2 was used to georeference the images. Image to map rectification was employed as described by Jensen (Jensen, 2005). An ortophoto map was used to derive ground control points (GCP). As lakes are dynamic environments, lack of good quality GCP was evident. Only objects, which had the same shape on orthophoto map and image, were utilised. However, this did not always allow enough GCP to be derived. As it appeared that stands of Scirpus lacustris did not change their location during time, they were used as GCP. Generally, 8 to 10 GCP were utilised for each of the images dated from 1956 to 1972, but the maximum was 14 GCP. As the 1981 images are larger, more GCP were utilised. The range was from 11 to 34 , and the average number is 16 . Second order polynomial transformation was employed to rectify images.

The georeferencing accuracy was assessed by RMS error. Acceptable RMS error was defined to be 5. However, no one image had a RMS error greater than 4. Average RMS error was 2.3 for 1956, 1.6 for 1972 and 2.7 for 1981. GCP was not derived from the area where images from the same

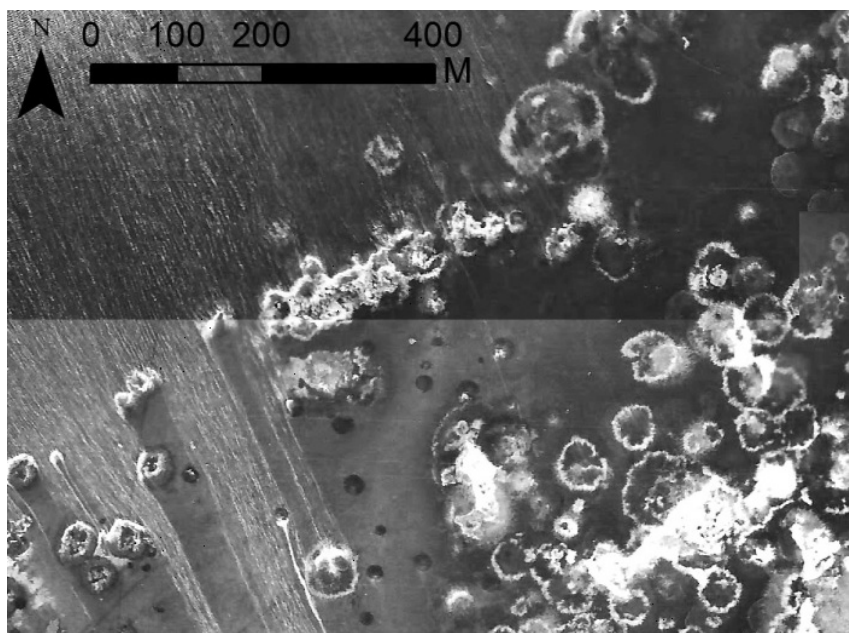

Fig. 2. Fragment of aerial photography acquired in 1956. Brightness differences, shades, texture of water are features that prohibit the use of automatic classification.

year were overlapping to avoid cumulative errors. Central parts of each image were employed in the study, where possible, as georeferencing errors tended to increase towards the edges of the images.

Historical aerial photography quality varied from year to year and from image to image. Differences in the level of brightness was given as a reason for employing manual classification in the study of coastal submerged plants (Frederiksen et al., 2004). This was also frequent in the images of Lake Engure (Fig. 2). Waves also cause pixel differences from almost black to almost white. Shades are another issue. Some areas are very bright. Images of 1956 were especially difficult for automated analysis. For the above reasons, most studies using historical aerial photographs employ visual interpretation (Lehmann and Lachavanne, 1998). In several studies, visual interpretation was also been used as a tool to evaluate the results of automated classification (Valta-Hulkonen et al., 2004; Liira et al., 2010).

Visual interpretation was performed in ESRI ArcGIS 9.3 and Quantum GIS Encelados.

Emergent macrophytes and water borders always were not distinctive, with a fuzzy transition zone often appearing. Therefore, visual interpretation always is associated with a bias.

A scale of 1:2000 was used to distinguish two classes water or aquatic vegetation - within a chosen frame. The frame was derived from a topographical map. It was generalised from the 1st isohypse or forest borders, whichever was closer to lake. Vegetation or open water patches smaller than $25 \mathrm{~m}^{2}$ were excluded from the study.

Lake Engure was divided into 13 aquatoriums based on continuous emergent vegetation or water regions (Fig. 1). The dynamics of emergent macrophytes were analysed in territories with different depth, using a step of $0.5 \mathrm{~m}$. 


\section{RESULTS}

The area of emergent macrophytes expanded by 781 ha from 1956 to 2007, which equates to a rate of approximately 15 ha, annually.

Even with this limited amount of available data, differences in the rate of expansion occurred between periods. Lake Engure experienced a dramatic increase (501 ha in total, or 31 ha/year) of emergent macrophytes from 1956 to 1972 (Fig. 3). The expansion of emergent macrophytes since 1972 has been slower. This is especially true from 1972 to 1994, when the total increase was only 137 ha (6 ha/year). A slightly faster increase was recorded from 1994 to 2007, when the area covered by emergent macrophytes increased by 143 ha (11 ha/year). A rapid increase of emergent macrophytes (289 ha) from 1994 to 2004 and a subsequent decrease (127 ha) from 2004 to 2007 was recorded. These changes should be explained by the time when remote sensing data was acquired.

Open water territories decreased by $1.11 \%$ yearly from 1956 to 1972 (Fig. 4). The decrease was much slower from 1972 to $1994(0.25 \%)$, while it doubled from 1994 to 2007 (Fig. 2). The open water area declined from $30.7 \mathrm{~km}^{2}$ in 1956 to $25.7 \mathrm{~km}^{2}$ in $1972,25.1 \mathrm{~km}^{2}$ in $1981,24.3 \mathrm{~km}^{2}$ in 1994 and finally $22.9 \mathrm{~km}^{2}$ in 2007.

According to bathymetry data of the topographical map, the area of Lake Engure with a depth between $0.5 \mathrm{~m}$ and $1.0 \mathrm{~m}$ is 808 ha. Emergent macrophytes have been mostly restricted to those parts of the lake. A steady increase has been recorded in this area, from 5 ha in 1956 to 15 ha in 1994 and 21 ha in 2007 in those parts. The relative area of emergent macrophytes in these territories increased from $0.6 \%$ to $2.6 \%$. The area of Lake Engure where depth exceeds $1 \mathrm{~m}$ is $471 \mathrm{ha}$; in this region the area of emergent macrophytes was very low ( 0.3 to $0.4 \mathrm{ha}$ ).
Most of the expansion occurred in territories that were shallower than $0.5 \mathrm{~m}$. Therefore, it was particularly important to analyse these territories.

Different parts of the lake showed various patterns of macrophyte increase (Fig. 5). Aquatoriums 7 and 9 experienced the slowest increase of emergent macrophytes. A steady and strong expansion of emergent macrophytes was characteristic of aquatoriums 1 and 11. Aquatorium 12 characterised the average increase of emergent macrophytes in the whole lake. Aquatorium 4 experienced the fastest increase of emergent macrophytes, especially from 1956 to 1972. Aquatoriums 3, 5 and 10 had strong increases during the entire study period; but after 1972 the expansion was somewhat slower. Since 1972 the expansion of emergent macrophytes was low in aquatorium 2.

Water level data of Lake Engure indicates that spring maximal water level significantly increased from 1972 to 1994 , and decreased from 1994 to 2007. A faster increase of emergent macrophytes and decrease of water level from 1994 to 2007 was observed, while the period of slower increase co-occurred with an increase of water level.

\section{DISCUSSION}

The study showed that Lake Engure has experienced massive emergent macrophytes expansion during the last 50 years. The area covered by emergent macrophytes has increased by 781 ha, while open water territory has decreased by $0.57 \%$ per year.

Study of Auniňš et al. (2000) showed that Phragmites australis was the dominant emergent macrophyte species in Lake Engure. It is impossible to distinguish this species from others in the historical aerial photographs. However, it is possible to distinguish emergent vegetation from other types of vegetation. Stands of emergent macrophytes are often sparse. Therefore, it was necessary to set a threshold for
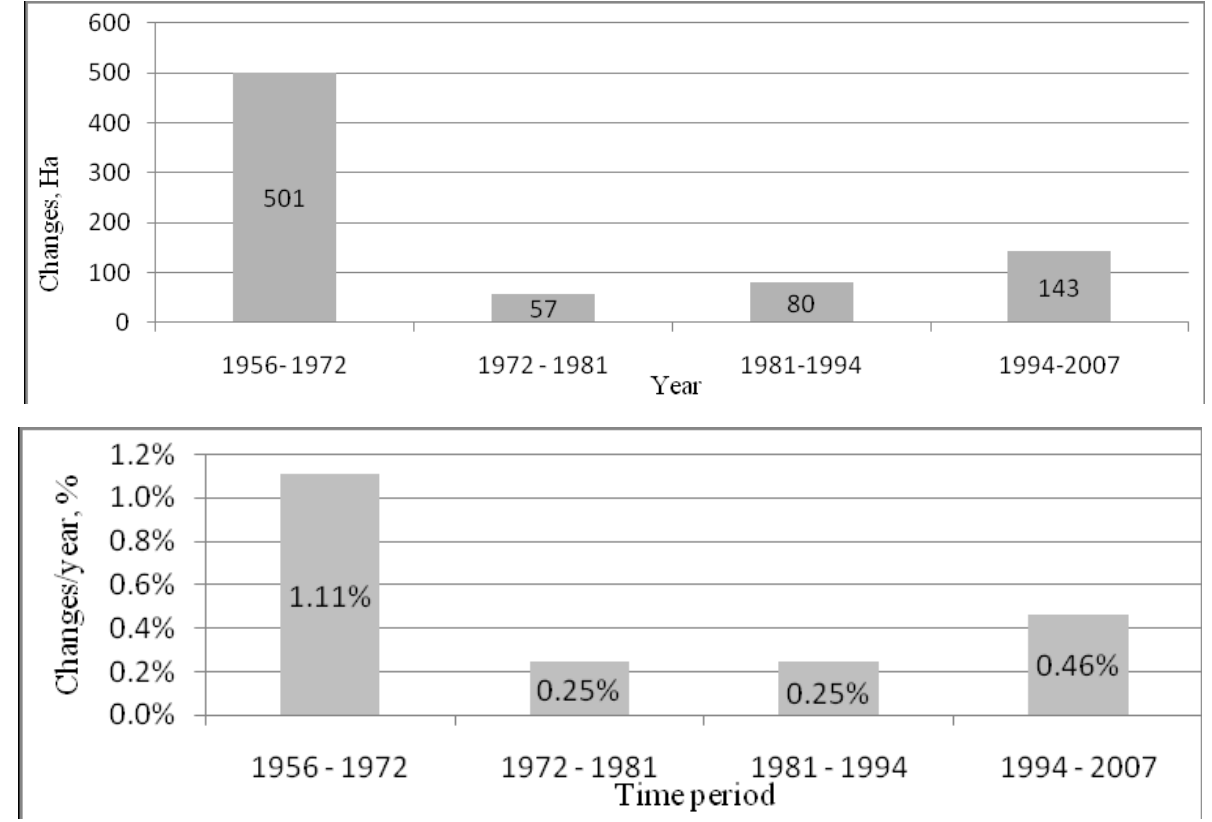

Fig. 3. Expansion of emergent macrophytes by study periods.

Fig. 4. Speed of decrease of open water territory over 50 years. 


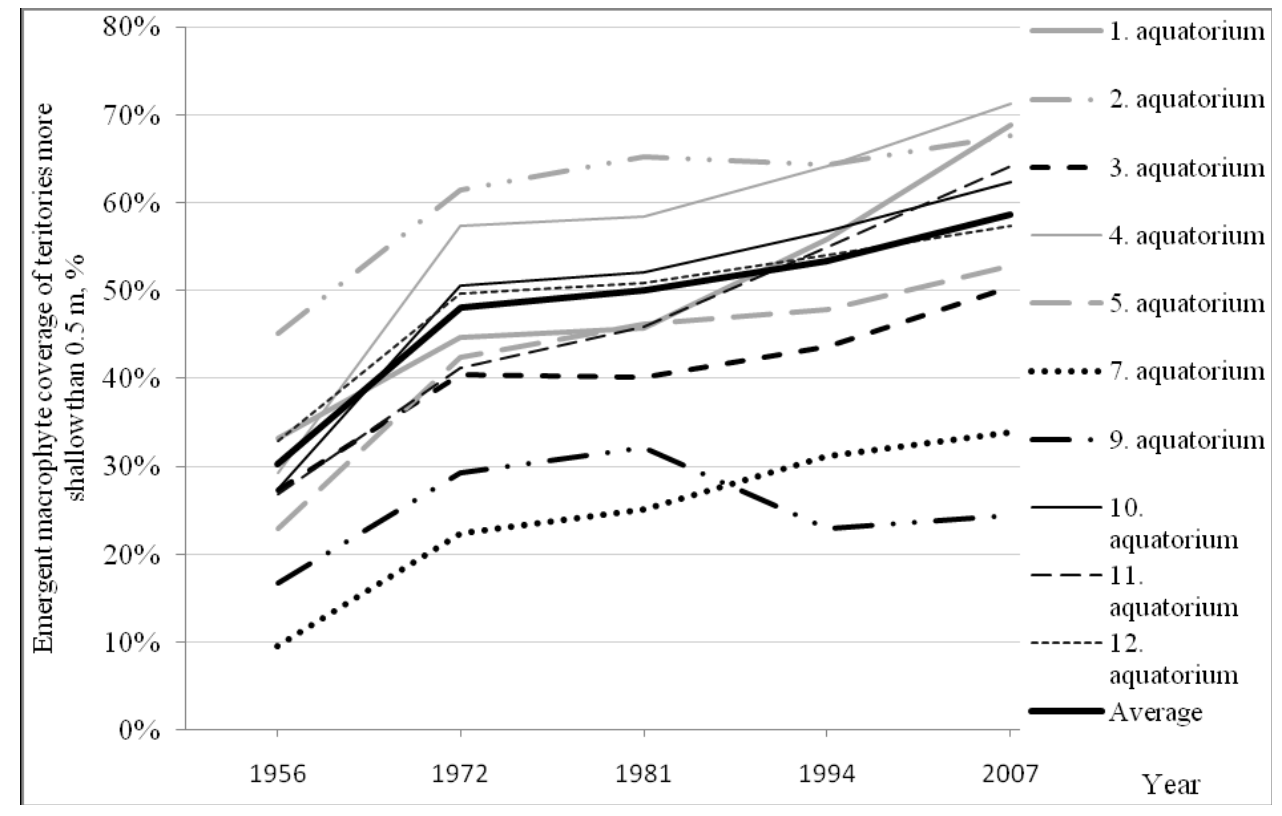

Fig. 5. Emergent macrophyte coverage of territories shallower than $0.5 \mathrm{~m}$ in selected aquatoriums. For locations of aquatoriums see Fig. 1. definition of the borders of emergent macrophyte patches. In this regard, this study may have a bias, but as the author performed the interpretation of all material, a significant systematic error is not likely.

Expansion of emergent macrophytes was highest in the period from 1956 to 1972 . The area covered by emergent macrophytes increased by 501 ha during this period, while open water territory decreased by $1.11 \%$ per year. At the beginning of this time period, meadows of Lake Engure were grazed by cattle and horses and hay was harvested, but because of establishment of an ornithological reserve in Lake Engure in 1957 and other factors, grazing and hay harvesting was ceased at the beginning of the 1960s (Vìksne, 1997). This may be the main reason why there was such a vast increase of emergent macrophytes, especially of reeds, during this time period.

Some studies of lake overgrowth by emergent vegetation have also been performed in other European countries. It has been reported that lake overgrowth by reeds in Sweden became a problem in the late 1960s (Anderson, 2001). Overgrowing was observed earlier in Lake Engure, and was most severe between 1956 and 1972; later expansion of emergent macrophytes has been moderate or even low. It means that this problem arose earlier in Lake Engure than in Sweden.

The land surrounding Lake Engure is mostly covered by forest, with agricultural land use in the drainage basin located about $10 \mathrm{~km}$ from the lake (Eberhards and Saltupe, 2000). This might lead to low nutrient input to the Lake. Lake Engure has high hydrogen carbonate ion concentration $\left(150 \mathrm{mg} / \mathrm{l}^{-1}\right)($ Briede et al., 2000), which is a factor associated with lower nutrient availability (Wetzel, 2001). Thus, eutrophication might be relatively weak in the lake, despite its shallowness.

The change in area of open water territory occurred in the opposite direction to that of emergent macrophytes, which indicates the main change in vegetation over the study period. Expansion of emergent macrophyte area slowed down after 1972 in Lake Engure. The decrease in open-water territory was slower by more than four times $(0.25 \%)$ from 1972 to 1994 when compared to the previous period $(1.11 \%)$. Open water territory decreased about twice faster $0.46 \%$ per year from 1994 to 2007, than in the previous two periods, while the emergent macrophyte covered area increased.

A study of Lake Võrtsjärv showed that the increase in area of emergent macrophytes was significantly larger (by 369 ha from 1985 to 2007) than in Lake Engure (by 223 from 1981 to 2007) in a longer time period, while many shallow coastal areas of Lake Võrtsjärv remained unvegetated (Liira et al., 2010). Lake Võrtsjärv is much larger than Lake Engure, but in Lake Engure the Phragmiteum community alone covered $19 \mathrm{~km}^{2}$ in 1997 (Auniņš et al., 2000), while the total area of emergent macrophytes in Lake Võrtsjärv was less than $12 \mathrm{~km}^{2}$ in the period 2006-2007 (Liira et al., 2010). Thus, the proportional increase of emergent macrophytes has been much smaller in Lake Engure.

Unpublished assessments suggest that this process has been much more intensive in Lake Papes (Latvia), which has a similar morphology. Area of aquatic vegetation, mostly emergent macrophytes, increased in Lake Luupuvesi (Finland, area $\sim 7 \mathrm{~km}^{2}$, mean depth $\sim 1 \mathrm{~m}$ ) from 96 ha in 1953 to 355 ha in 1996 (Valta-Hulkonen et al., 2004). Another study in Finland showed that in lakes not subjected to high water level from 1947-1963 to 1996-2000, emergent macrophytes increased for about 50 to $70 \%$ (Partanen and Hellsten, 2005). However, it is difficult to compare these lakes with Lake Engure, because used different methods were used for assessing the rates of overgrowth. Despite that, it seems that the rates of overgrowth in Lake Engure are slower than those of the lakes discussed above. Do we have to look for reasons, which accelerate reed growth in Lake Engure or for those, which have altered it? 
It is important to note that the dynamics of growth of macrophytes can differ significantly between different parts of lake, depending on local conditions. The most notable difference was between aquatorium 7 and 9, where expansion of emergent macrophytes was limited, and the other aquatoriums. Wave disturbance is one of the factors affecting the spread of emergent macrophytes (Anderson, 2001). These aquatoriums are in the eastern part of the lake, where stronger wave action could prevent reed expansion.

Discharge of Lake Engure takes place in Northern part of the lake, where it is considerably narrower than the rest of the lake. There were rather large open water territories in 1956 in that area and water could easily flow to Mersraga Channel. However, already in 1972, only one open path remained for water flow. Water flow through a reed belt is possible also, however, it is much slower. The author has visually observed that the path is like a river; the flow is rather strong and path is rather deep. Aquatorium 1 had the largest increase of emergent macrophytes since 1972 (Fig. 6). This territory is separated from the rest of the lake by reed beds and only a narrow path is evident (Fig. 4).

Aquatoriums 4 and 10 experienced a very large increase of emergent macrophytes from 1956 to 1972; this could be due to the ceasing of hay harvest and grazing. Later, from 1972 to 1981 , there was almost no increase. There are many other differences in dynamics of emergent macrophytes, however, these differences are difficult to explain.

Research in Lake Võrtsjerv indicated that emergent macrophytes, particularly Phragmites australis, may expand to a water depth of up to $1.9 \mathrm{~m}$ (Feldman and Noges, 2007). Some emergent macrophytes species may grow even in a depth of up to $2.2 \mathrm{~m}$ (Anderson, 2001). Thus, the entire area of Lake Engure is suitable for emergent macrophytes However, the results indicate that emergent macrophytes in Lake Engure have been largely limited to a water depth $0.5 \mathrm{~m}$. It is well established that germination of Phragmites australis is possible only in very shallow water $(5 \mathrm{~cm}$ might be the threshold) or wet land. Therefore, the expansion is usually due to clonal spread and fragmentation (Engloner, 2009).

Overgrowth of emergent macrophytes is considered to be a shore process (Anderson, 2001; Partanen and Luoto, 2006; Liira et al., 2010). However, in Lake Engure it is difficult to consider it as a shore process, because of the lake morphology and very wide shallow zones. In some places the reed belt width is close to $2 \mathrm{~km}$ wide, covering almost half of the lake width. Therefore, statistics of reed belt width, which have been calculated in similar studies (Feldman and Nõges, 2007; Liira et al., 2010) are not comparable to the situation in Lake Engure, where the results largely depend from chosen shore line.

Not only are the yearly dynamics of emergent macrophytes important, but also seasonal changes. Seasonal variations of emergent macrophyte biomass have been described (Engloner, 2009). The time of optimal remote sensing information acquisition for emergent macrophytes mapping is late summer (Partanen and Hellsten, 2005; Liira et al., 2010). However, the researcher is dependent on remote sensing data gathered in the past (Dahdouh-Guebas and Koedam, 2008). The area covered by emergent macrophytes in Lake Engure in October, 2004 was significantly larger than that in June three years later and 10 years earlier. The acquired results appear to be consistent, when seasonal variation of emergent macrophytes is considered and the 2004 data is excluded. Therefore, the seasonal time of acquisition of remote sensing date needs to be standardised. More studies about seasonal dynamics of emergent macrophytes are required.

Some of the methodical issues should be discussed, which might have a considerable effect on study results. This is especial true in relation to the absolute area of emergent
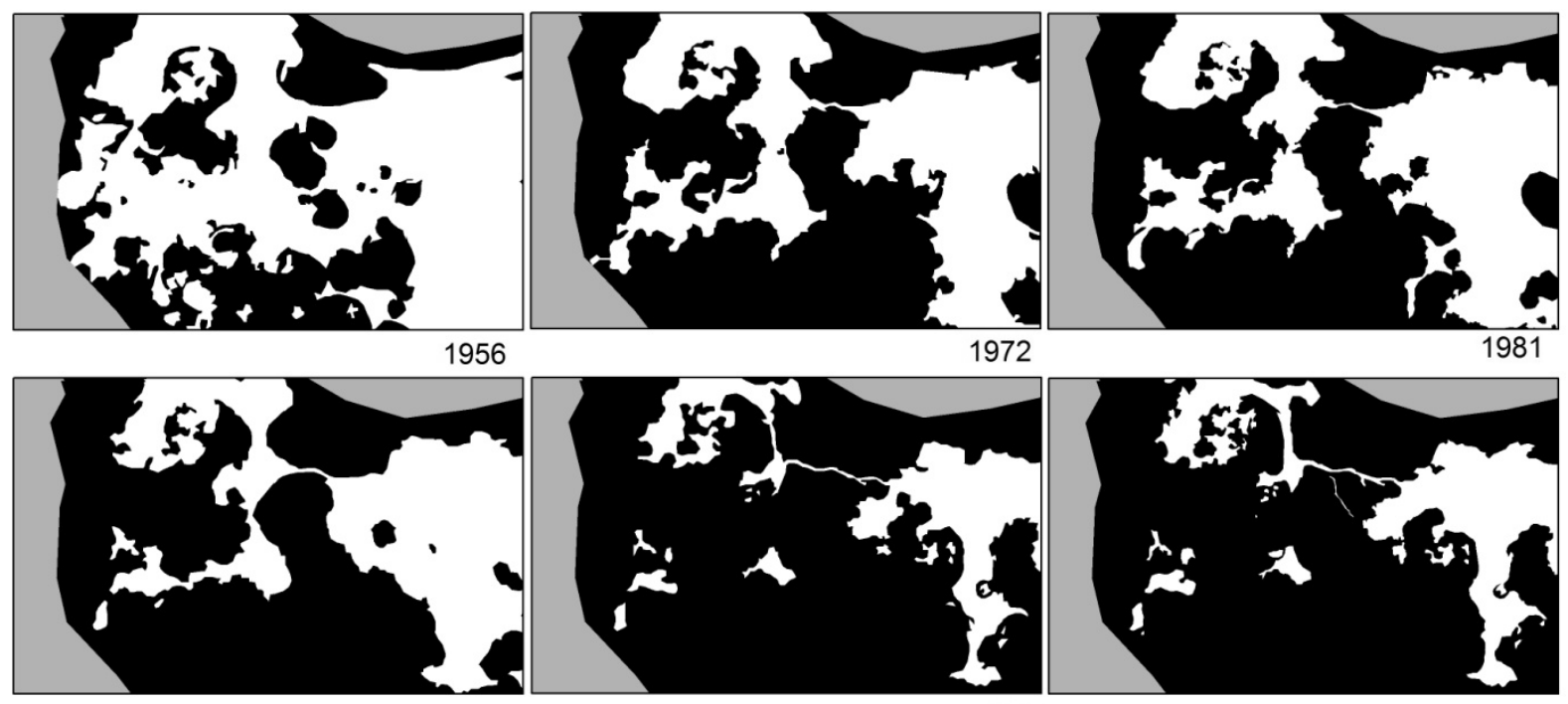

1994

Fig. 6. Comparison of the situation from all studied years. Emergent macrophytes are in black colour, open water territories are in white colour and territory outside the study area is in gray colour. 
macrophytes. Therefore, such results were not presented in this study. Accuracy of the absolute area of emergent macrophytes is not certain, as the terrestrial and aquatic vegetation border was estimated. However, the accuracy of the reported differences was high, as the same landward border was used in all cases. In a previous study, the border of Lake Engure was assumed from topographical maps (Auniņš et al., 2000). However, it is evident that in 1956 there were open water territories outside of the lake as in the topographical map. Therefore, a different approach was used. The spectral signature of emergent macrophytes and terrestrial vegetation largely overlap (Liira et al., 2010), and it is difficult to detect the border by interpretation of remote sensing data. Thus, either the first horizontal or forest border was used. Whichever is closest to the lake is justifiable, as it allows the analysis of dynamics of the whole lake.

As a significant part of Lake Engure was not covered by aerial photography, it is important to assess possible errors due to the data extrapolation. Two different techniques can be used for the data extrapolation. The technique used in Lake Constance (Schmieder et al., 2004) allowed extrapolation of the data available to the rest of the lake. Another method is based on temporal extrapolation of the data from one year to predict the missing data in another year.

Data from the year 1972 missed $29.4 \%$ of the lake. Emergent macrophytes from 1956 to 2007 expanded by 5.7 ha in this territory, while in the rest of the lake the increase was $25.6 \mathrm{ha}$ /annum (Fig. 7). Thus, the increase of emergent macrophytes in territories where the data for the year 1972 was not available, contributed $18.2 \%$ of the total increase; from 1981 to 1994 amounting to $17.5 \%$ and from 1994 to 2007 to $25.4 \%$. This means that the expansion of emergent macrophytes was much slower in areas of the lake where no data from 1972 was available. However, differences vary, and therefore it is not possible to extrapolate macrophyte expansion in those areas from the rest of the lake. Actually, such extrapolation would yield a 155 ha decrease of emergent macrophyte area from 1972 to 1981 and about a decrease of 190 ha in the territory which was not covered by 1972 data. Thus, the error of such extrapolation might be up

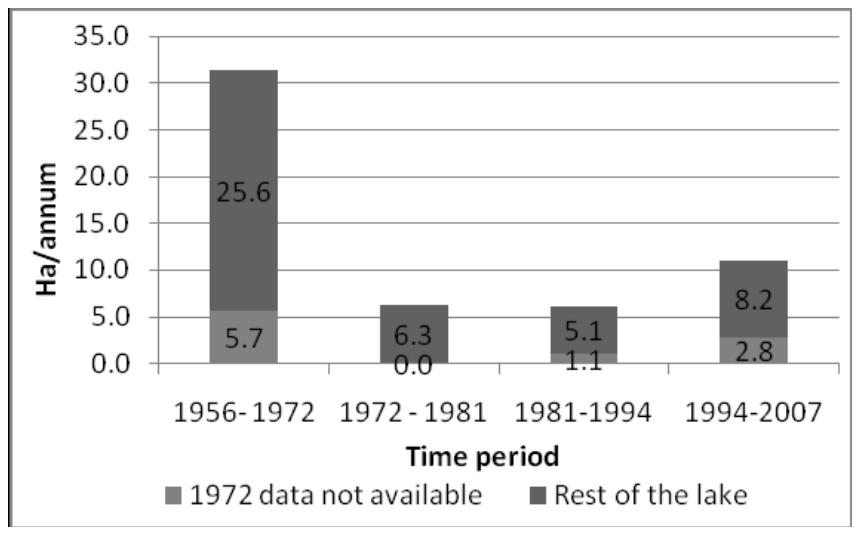

Fig. 7. Emergent macrophyte expansion during the 50 years. The upper part of each column represents the increase in area of emergent macrophytes where data from all investigated periods were available, while the bottom part represents the remaining parts of the lake. to 190 ha, while the extrapolation method used in this study might result in about 10 ha error.

Further study of Lake Engure is required to explain the differences between the aquatoriums.

\section{ACKNOWLEDGEMENTS}

Author is grateful to Prof. Janis Vìksne and Prof. Viesturs Melecis for assistance in preparation of the article. The author acknowledges financial support from the European Social Fund project Nr. 2009/0162/1DP/1.1.2.1.1/09/IPIA/ VIAA/004.

\section{REFERENCES}

Anderson, B. (2001). Macrophyte development and habitat characteristics in Sweden's large lakes. Ambio, 20(8), 503-515.

Auninšs, A., Zviedre, E., Brūmelis, G. (2000). Preliminary results of remote sensing based vegetation mapping of lake Engures (Engure), Latvia. Proc. Latvian Acad. Sci., Sect. B, 54(5), 170-176.

Briede, A., Kḷaviňš, M., Rodinovs, V. (2000). Chemical compositions of Lake Engures (Engure), Latvia. Proc. Latvian Acad. Sci., Sect. B, 54(5), 160-163.

Dahdouh-Guebas, F., Koedam, N. (2008). Long-term retrospection on mangrove development using transdisciplinary approaches: A review. Aquat. Bot., 89(2), 80-92.

Dekker, A.G., Brando, V.E., Anstee, J.M. (2005). Retrospective seagrass change detection in a shallow coastal tidal Australian lake. Rem. Sensing Environ., 97(4), 415-433.

Eberhards, G., Saltupe, B. (2000). Geological history, relief, and deposits of Lake Engure area along the Baltic Sea. Proc. Latvian Acad. Sci., Sect. B, 54(5), 141-147.

Engloner, A.I. (2009). Structure, growth dynamics and biomass of reed (Phragmites australis): A review. Flora, 204(5), 331-346.

Feldman, T. Nõges, P. (2007). Factors controling macrophyte distribution in large shallow Lake Võrtsjärv. Aquat. Bot., 87(1), 15-21.

Fredriksen, M., Krause-Jensen, D., Holmer, M., Sund Laursen, J. (2004). Long-term changes in area distribution of eelgrass (Zostera marina) in Danish coastal waters. Aquat. Bot., 78(2), 167-181.

Gavrilova, Ģ., Baroniņa, V. (2000). Vascular plant flora of the lake Engures (Engure) drainage basin, Latvia, and the coastal zone of the Gulf of Riga. Proc. Latvian Acad. Sci., Sect. B, 54(5), 177-189.

Jenesn, J.R. (2005) Introductory Digital Image Processing: A Remote Sensing Perspective, $3^{\text {rd }}$ edn. Upper Saddle River: Pearson Prentice Hall. $536 \mathrm{pp}$.

Lampert, W., Sommer, U. (2007). Limnoecology, $2^{\text {nd }}$ edn. Oxford: Oxford University Press. 235 pp.

Lehmann, A., Lachavanne, J.B. (1997). Geographical information systems and remote sensing in aquatic botany. Aquat. Bot., 58(3-4), 195-207.

Liira. J., Feldman, T., Mäemets, H., Peterson, U. (2010). Two decades of macrophyte expansion on the shores of a large shallow northern temperate lake: A retrospective series of satelite images. Aquat. Bot., 93(4), 207-215.

Nõges, P., Kangur, K., Nõges, T., Reinart., A. Simola, H., Viljanen, M. (2008). Highlights of large lake research and management in Europe. Hydrobiologia, 599(1), 259-276.

Partanen, S., Hellstenm S. (2005). Changes of emergent aquatic macrophyte cover in seven large boreal lakes in Finand with special reference to water level regulation. Fennia, 183(1), 57-79.

Partanen, S., Luoto, M. (2006). Environmental determinants of littoral paludification in boreal lakes. Limnologica, 36(2), 98-109. 
Schmieder, K., Dienst, M., Ostendorp, W., Jöhnk, K. (2004). Effects of water level variations on the dynamics of the reed belts of Lake Constance. Ecohydrol. Hydrobiol., 4(4), 229-240.

Schmitz, D., Blank, M., Ammondt, S., Patten, D.T. (2009). Using historic aerial photography and paleohydrologic techniques to assess long-term ecological response to two Montana dam removals. J. Environ. Manag. 90(3), S237-S248.

Sprinğe, G., Druvietis, I., Parele, E. (2000). The plankton and benthos communities of the lagoon lake Engures (Engure), Latvia. Proc. Latvian Acad. Sci., Sect. B, 54(5), 164-169.

Received 9 November 2011
Valta-Hulkkonen, K., Kanninen, A., Pellikka, P. (2004). Remote sensing and GIS for detecting changes in the aquatic vegetation of rehabilitated lake. Int. J. Rem. Sensing, 25(24), 5745-5758.

Vìksne, J (2000). Changes of nesting bird fauna at the Engure Ramsar site Latvia, during the last 50 years. Proc. Latvian Acad. Sci., Sect. B, 54(5), 213-220.

Viksne, J. (1997). The Bird Lake Engure. Rīga: Jāņa sēta, 111 pp.

Wetzel, R.G. (2001). Limnology: Lake and River Ecosystems, $3^{\text {rd }}$ edn. San Diego: Academic Press. 1006 pp.

Zelcs, V., Markots, A. (2004). Deglaciation history of Latvia. In: Developments in Quaternary Science. Quaternary Glaciations Extent and Chronology. Part I: Europe. (pp. 225-243). Ehlers, E., Gibbard, P.L. (eds.). Amstedam: Elsevier.

\section{VIRSŪDENS AUGU DINAMIKA PUSGADSIMTA GARUMĀ LATVIJAS PIEKRASTES EZERĀ - ENGURES EZERĀ}

Engures ezers ir sekls liela izmēra piekrastes ezers, kurš iekḷauts Ramsāres vietu sarakstā kā starptautiski nozīmīgs unikāls mitrājs ar augstu bioloğisko daudzveidību. Pētîta virsūdens augu dinamika, balstoties uz vēsturisko aerofotogrāfiju un digitālo ortofoto karšu analīzi. Virsūdens augu segums laika posmā no 1956. gada līdz 2007. gadam ir pieaudzis par 781 ha (15 ha/gadā). Augāja ekspansija nav bijusi vienmērīga. Laika posmā no 1956. gada līdz 1972. gadam tā ir bijusi loti strauja (31 ha/gadā), no 1971. gada līdz 1994. gadam samazinājusies līdz 6 ha/gadā, bet no 1994. gada līdz 2007. gadam atkal palielinājusies līdz 11 ha/gadā. Virsūdens augu straujo attīstību no 1956. gada līdz 1972. gadam var izskaidrot ar plaušanas un ganī̌sanas pārtraukšanu. Virsūdens augu segums mainās sezonāli, tāpēc var tikt salīdzināti tikai vienas un tās pašas sezonas tālizpētes materiāli. Atklāta ūdens platība 2007. gadā bija tikai $22.9 \mathrm{~km}^{2}$, salīdzinājumā ar 30.7 $\mathrm{km}^{2}$ 1956. gadā. Virsūdens augu izplatība galvenokārt notiek akvatorijās, kur dziḷums ir lielāks par 0.5 m. Dažāāas Engures ezera dạ̦ās virsūdens augu dinamika ir atšķirīga. Galvenie faktori, kas ietekmē to izplatību ir vējšs, hidroloğiskā režīms un lauksaimnieciskās darbības izbeigšanās ezera piekrastē. 